\title{
Lauric Acid Beneficially Modulates Apolipoprotein Secretion and Enhances Fatty Acid Oxidation via PPARa-dependent Pathways in Cultured Rat Hepatocytes
}

\author{
Sakunthala Arunima and Thankappan Rajamohan* \\ Department of Biochemistry, University of Kerala, Thiruvananthapuram-695581, India
}

\begin{abstract}
Background and objectives: Dietary fat type can differentially modulate the fatty acid oxidation and secretion of lipoproteins in hepatocytes. The purpose of the present study was to investigate how the nature of fatty acids present in dietary oils influences fatty acid oxidation as well as secretion of apolipoproteins.
\end{abstract}

Methods: Primary rat hepatocytes were cultured with major fatty acids present in common cooking oils, which vary in their degree of saturation: viz. coconut oil (lauric acid; C12:0); olive oil (oleic acid; C18:1); and sunflower oil (linoleic acid; C18:2). Each fatty acid was used at a dose of $500 \mu \mathrm{M}$ for 12 hours.

Results: Cells treated with laurate beneficially modulated the secretion of apolipoproteins relative to cells treated with oleate and linoleate $(p<0.05)$. These results correlated with the respective apolipoproteins' mRNA expression. Laurate increased activities and mRNA expression of enzymes involved in $\beta$-oxidation (viz. carnitine palmitoyl transferase I and acyl CoA oxidase) and also up-regulated the respective transcription factor, peroxisome proliferator-activated receptor alpha (PPAR $\alpha)$, when compared to other fatty acids $(p<0.05)$. Studies using the PPAR $\alpha$ agonist WY 14643 revealed that lauric acid may act as a natural ligand for PPAR $\alpha$ and mediates its effects partly via PPAR $\alpha$-dependent pathways in hepatocytes.

Conclusions: These results clearly indicate that lauric acid, the major fatty acid present in oil extracted from coconut, acts as a natural ligand for PPAR $\alpha$, beneficially regulating secretion of apolipoproteins and enhancing fatty acid oxidation via PPAR $\alpha$ signaling pathways in hepatocytes.

\section{Introduction}

It has been known for many years that the type of fat in the diet influences blood lipid levels and, consequently, the risk for development of atherosclerosis and related cardiovascular diseases. ${ }^{1}$ Epidemiological and clinical studies have consistently demonstrated that human serum lipid concentration may be altered by

Keywords: Apolipoprotein A1; Apolipoprotein B; Carnitine palmitoyl transferase-I; Oleic acid; Virgin coconut oil.

Abbreviations: PPAR $\alpha$, peroxisome proliferator-activated receptor alpha; SEM, standard error of the mean.

Received: March 12, 2017; Revised: September 02, 2017; Accepted: September 06, 2017

*Correspondence to: Thankappan Rajamohan, Department of Biochemistry, University of Kerala, Thiruvananthapuram-695581, India. E-mail: trmohanbio@gmail.com How to cite this article: Arunima S, Rajamohan T. Lauric Acid Beneficially Modulates Apolipoprotein Secretion and Enhances Fatty Acid Oxidation via PPAR $\alpha$-dependent Pathways in Cultured Rat Hepatocytes. J Explor Res Pharmacol 2018;3(1):1-11. doi: 10.14218/JERP.2017.00008. diet, which is itself mostly influenced by the nature of dietary fatty acids present in it, particularly differences in the chain length, degree of unsaturation, position and stereo-isomeric configuration of the double-bonds as well as the bioactive components present in dietary oils. ${ }^{2}$ Although plasma low-density lipoprotein is well established as a predictor of cardiovascular disease, recent observations have revealed that apolipoproteins may in fact be more powerful lipid-related predictors of cardiovascular disease risk. ${ }^{3,4}$ Among them, apolipoprotein B is the chief protein component of atherogenic lipoprotein particles and apolipoprotein A1 is the major apolipoprotein constituent of the anti-atherogenic high-density lipoproteins in animal models. ${ }^{5}$ Apolipoprotein E also acts as a key regulator of plasma lipid level and plays an important role in cholesterol transport. ${ }^{6}$

In vitro cell culture studies have shown that availability of lipid is a critical factor in the assembly and secretion of lipoproteins. ${ }^{7}$ There are reports that $\beta$-oxidation of fatty acids, as well as synthesis and assembly of lipoproteins, is coordinated via transcriptional regulation. ${ }^{8}$ Experimental evidence has revealed that peroxisome proliferator-activated receptor alpha $(\mathrm{PPAR} \alpha)$ activation regulates 
fatty acid oxidation as well as metabolism of both high-density lipoproteins and apolipoprotein B-containing lipoproteins in rodents and humans. ${ }^{9,10}$ Studies have suggested that PPAR $\alpha$ connects fatty acid oxidation to synthesis of apolipoproteins; PPAR activation leads to increased hepatic oxidation of fatty acids and less synthesis of triglycerides for very low-density lipoprotein assembly. ${ }^{11}$

Gas chromatography-mass spectrometry analysis of the test oils revealed that there were no significant differences in fatty acid composition among the two types of coconut oil extracted by different modes of extraction (copra oil and virgin coconut oil), which contained mostly short and medium chain fatty acids and were mainly composed of lauric acid (C12:0; 46\%). But, olive oil contains $62 \%$ oleic acid $(\mathrm{C} 18: 1)$ and sunflower oil contains higher amounts of linoleic acid (C18:2; 47\%). ${ }^{12}$ Later on, studies using these test oils found that supplementation of virgin coconut oil extracted from fresh coconut kernel produced a significant effect on lowering blood lipid levels, mostly reflected in their corresponding apolipoprotein levels (a significant decrease in apolipoprotein B and an increase in apolipoprotein A1 levels) compared to monounsaturated fatty acid-rich olive oil and polyunsaturated fatty acid-rich sunflower oil in rats. ${ }^{13}$ Moreover, there are reports that a polyunsaturated fatty acid enriched diet enhances high-density lipoprotein turnover, which was found to be associated with higher fractional catabolic rates for both apolipoprotein A1 and apolipoprotein AII relative to saturated and monounsaturated oils. ${ }^{14,15}$

It has also been established that oleic acid exerts a concentration-dependent increase in apolipoprotein B secretion from cultured rat hepatocytes into the medium, relative to cells treated with saturated or polyunsaturated fatty acids. ${ }^{16}$ However, the effect of lauric acid on apolipoprotein secretion and fatty acid oxidation is not yet understood. Our recent reports demonstrated that virgin coconut oil supplementation up-regulates PPAR $\alpha$-mediated fatty oxidation pathways in vivo, as compared to the monounsaturated fatty acid-rich olive oil and polyunsaturated fatty acid-rich sunflower oil in rats. ${ }^{17}$ In view of these findings, detailed studies were carried out to investigate the relative effects of major fatty acids present in these test oils (viz. lauric acid (C12:0), oleic acid (C18:1) and linoleic acid (C18:2)) on fatty acid oxidation and apolipoprotein secretion in primary rat hepatocytes. The role of PPAR $\alpha$ pathways in fatty acid-mediated apolipoprotein secretion and fatty acid oxidation in hepatocytes were also elucidated.

\section{Methods}

\section{Chemicals}

TRI Reagent, oligonucleotides, primers for PCR, anti-rabbit IgG, Eagle's minimum essential medium, penicillin, streptomycin, type IV collagenase, lauric acid, oleic acid, linoleic acid, the MTT tetrazolium dye and WY 14643 were purchased from Sigma Aldrich Co. (St Louis, MO, USA). Antibodies against apolipoprotein A1 and apolipoprotein B were obtained from Santa Cruz Biotechnology (Dallas, TX, USA). cDNA synthesis and PCR reactions were carried out using kits purchased from Fermentas, Thermo Fisher Scientific Inc. (Canada). All chemicals used were of the highest analytical grade.

\section{Preparation and maintenance of hepatocytes}

Hepatocytes were isolated from normal rats (Sprague-Dawley strain) by collagenase perfusion. ${ }^{18,19}$ Hepatocytes $\left(0.65 \times 10^{6}\right.$ cells/
$\mathrm{mL}$ in Eagle's minimum essential medium supplemented with $10 \%$ fetal bovine serum, non-essential amino acids and antibiotics) were seeded into $35 \mathrm{~mm}$ petri dishes. After $4 \mathrm{~h}$, the unattached cells were removed and the medium was changed to serum-free medium supplemented with $500 \mu \mathrm{M}$ fatty acids (laurate, oleate and linoleate) at a fatty acid: bovine serum albumin ratio of 2:1 and incubated for $12 \mathrm{~h}$. Untreated cells received an equal amount of bovine serum albumin equal to that brought with the bovine serum albumin-fatty acid complex.

\section{Preparation of albumin-bound fatty acids}

A $10 \mathrm{mM}$ stock solution of each fatty acid was prepared by diluting the free fatty acid in ethanol and precipitating it with the addition of $\mathrm{NaOH}(0.25 \mathrm{M}$ final concentration). Excess ethanol was evaporated under $\mathrm{N}_{2}$ gas, and the precipitated sodium salt was reconstituted with $0.9 \% \mathrm{NaCl}$ and stirred at room temperature for $10 \mathrm{~m}$ with defatted bovine serum albumin (final concentration of $10 \%$ in $0.15 \mathrm{M} \mathrm{NaCl}$ ). Each solution was adjusted to $\mathrm{pH} 7.4$ with $\mathrm{NaOH}$ and stored in multiple aliquots at $-20{ }^{\circ} \mathrm{C}$ protected from light, and tubes were purged with $\mathrm{N}_{2}{ }^{20}$

\section{Biochemical analysis}

The activities of enzymes involved in $\beta$-oxidation in hepatocytes (viz. carnitine palmitoyl transferase I and acyl CoA oxidase) were assayed. ${ }^{21,22}$ The MTT tetrazolium dye assay was performed according to the method described by Mosmann, ${ }^{23}$ which is directly correlated to cell viability; cell viability was calculated as a percentage from the viability of the control (untreated) cells.

\section{Enzyme-linked immunosorbent assay}

Enzyme-linked immunosorbent assay was carried out according to the procedure of $\mathrm{Lin}^{24}$ and the protein concentration was estimated by the method of Lowry et al. ${ }^{25}$ using Folin phenol reagent with bovine serum albumin as the standard.

\section{Isolation of total genomic RNA}

Total genomic RNA was isolated from the heart using TRI Reagent by the method described by Chomczynski and Mackey. ${ }^{26}$

\section{cDNA synthesis and semi-quantitative reverse transcription-PCR}

cDNA synthesis and reverse transcription-PCR reactions were performed in a thermocycler (Eppendorf AG, Hamburg, Germany) as per manufacturer's instructions using a kit purchased from Fermentas. The primers used were: apolipoprotein A1 (forward) 5'-GAAATGGAAAGAGGATGTGGAG-3' and (reverse) 5'-GT TCAAGGTAGGGTTGCTCTTG-3'; apolipoprotein B (forward) 5'-TAGAGGATCCCTGAGCAGGCTTCCTCAGCAG-3' and (reverse) 5'-TTTAAAGCTTCAATGATTCTATCAATAATCTG-3'; carnitine palmitoyl transferase I (forward) 5'-GGA GAC AGA CAC CAT CCAACA TA-3' and (reverse) 5'-AGG TGA TGG ACT TGT CAA ACC-3'; acyl CoA oxidase (forward) 5'-CTT TCT TGC TTG CCT TCC TTC TCC $3^{\prime}$ and (reverse) 5'-GCC GTT TCA CCG CCT CGT A-3'; PPAR $\alpha$ (forward) 5'-TCACACAATGCAATCCGTTT-3' and (reverse) 5'-GGCCTTGACCTTGTTCATGT-3'; 
Table 1. Effect of exogenous fatty acids on apolipoprotein secretion

\begin{tabular}{llllll}
\hline & Group I & Group II & Group III & Group IV & $p$-value \\
\hline${\text { Apolipoprotein } A 1^{*}}^{*}$ & $0.15 \pm 0.01^{\mathrm{a}}$ & $0.25 \pm 0.01^{\mathrm{b}}$ & $0.15 \pm 0.03^{\mathrm{a}}$ & $0.20 \pm 0.08^{\mathrm{d}}$ & $<0.05$ \\
${\text { Apolipoprotein } \mathrm{B}^{*}}$ & $0.29 \pm 0.01^{\mathrm{a}}$ & $0.40 \pm 0.01^{\mathrm{b}}$ & $1.25 \pm 0.05^{\mathrm{c}}$ & $0.80 \pm 0.05^{\mathrm{d}}$ & $<0.05$ \\
\hline
\end{tabular}

Values are mean \pm SEM of three separate experiments in triplicate. Values not sharing a common superscript differ significantly at $p<0.05$. Group I-control; Group II-500 $\mu \mathrm{M}$ laurate; Group III-500 $\mu \mathrm{M}$ oleate; Group IV-500 $\mu \mathrm{M}$ linoleate. *OD U/mg protein. Abbreviation: SEM, standard error of the mean.

and glyceraldehyde-3-phosphate dehydrogenase (forward) 5'-CCT TCA TTG ACC TCA ACT AC-3' and (reverse) 5'-GGA AGG CCA TGC CAG TGA GC-3'. The PCR reaction mixture contained cDNA, PCR master mix and appropriate primers. The reaction mixtures were incubated at $94{ }^{\circ} \mathrm{C}$ for $3 \mathrm{~m}$ for initial denaturation and cycled 35 times at $94^{\circ} \mathrm{C}$ for $30 \mathrm{~s}$ (template denaturation), primer annealing for $30 \mathrm{~s}$ at $72^{\circ} \mathrm{C}$ for $2 \mathrm{~m}$. After a final extension at $72^{\circ} \mathrm{C}$ for $10 \mathrm{~m}$, the PCR products were electrophoresed on $1.5 \%$ agarose gel and visualized by staining with ethidium bromide. The gels were subjected to densitometric scanning (Bio-Rad Gel Doc, Hercules, CA, USA) to determine the density of each band and then normalized against an internal control, glyceraldehyde3-phosphate dehydrogenase, using QuantityOne imaging software.

\section{Statistical analysis}

Data are presented as means with their standard errors. Statistical analysis was performed by one-way analysis of variance followed by Duncan's multiple range tests using the SPSS/PC (version 17.0; SPSS) software package program. A $p$-value $<0.05$ was considered significant.

\section{Results}

\section{Effect on apolipoprotein secretion}

In order to study how the nature of fatty acid influence on the secretion of apolipoproteins, hepatocytes were incubated with different fatty acids, including lauric acid (C12:0), oleic acid (C18:1) and linoleic acid (C18:2), each at a dose of $500 \mu \mathrm{M}$ for $12 \mathrm{~h}$ of exposure. At the end of the experimental period, the medium and cell layer were harvested. The medium was centrifuged for 10,000 $g$ for $15 \mathrm{~m}$ and was collected for apolipoprotein concentration by enzyme-linked immunosorbent assay. In the presence of laurate, there was a significant $(p<0.05)$ decrease in the apolipoprotein B secretion relative to oleate- and linoleate-treated cells. While treatment with oleate significantly $(p<0.05)$ increased the apolipoprotein B secretion compared to cells treated with other fatty acids.

Hepatocytes treated with linoleate decreased the apolipoprotein B secretion compared to oleate treatment (Table 1). Among the different fatty acids, oleate showed maximum effect on apolipoprotein B secretion (1.25 OD U/mg protein), followed by linoleate (0.80 OD U/mg protein), laurate (0.40 OD U/mg protein) and untreated cells $(0.29 \mathrm{U} / \mathrm{mg}$ protein $)$. In contrast, cells treated with laurate significantly $(p<0.05)$ increased the secretion of apolipoprotein A1 compared to cells treated with other fatty acids. While cells treated with oleate significantly $(p<0.05)$ reduced the apolipoprotein A1 secretion relative to laurate and linoleate treatment. Cells treated with linoleate significantly $(p<0.05)$ increased the apolipoprotein A1 secretion compared to cells treated with oleic acid (Table 1).

Among the different fatty acids, the saturated fatty acid laurate
(0.25 OD U/mg protein) showed maximum effect on apolipoprotein A1 secretion, followed by linoleate $(0.20 \mathrm{OD} \mathrm{U} / \mathrm{mg}$ protein) and oleate $(0.15 \mathrm{OD} \mathrm{U} / \mathrm{mg}$ protein), suggesting that the nature of fatty acids plays an important role in the synthesis and secretion of apolipoproteins in hepatocytes.

\section{Effect on mRNA expression of apolipoproteins in hepatocytes}

The results are summarized in Figure 1. In the presence of laurate, there was an up-regulation in the mRNA expression of apolipoprotein A1 in hepatocytes compared to cells treated with other fatty acids. Treatment with oleate decreased mRNA expression of apolipoprotein A1 relative to cells treated with laurate and linoleate. While treatment with linoleate increased apoA1 expression compared to oleate treatment. However, hepatocytes incubated with laurate showed a significant down-regulation in the mRNA expression of apolipoprotein B compared to incubation with the other fatty acids. Treatment with oleate showed a significant increase in apolipoprotein B mRNA expression compared to hepatocytes incubated with laurate and linoleate.

\section{Effect on fatty acid oxidation in hepatocytes}

For studying the effect of fatty acids present in dietary oils on fatty acid oxidation, the activities of major enzymes involved in fatty acid oxidation in hepatocytes (viz. carnitine palmitoyl transferase I and acyl CoA oxidase) were studied. The results indicate that hepatocytes treated with laurate have a significant increase in the activities of carnitine palmitoyl transferase I and acyl CoA oxidase compared to cells treated with other fatty acids (Table 2). The activities of these enzymes were found to be decreased in cells treated with oleate, relative to laurate and linoleate. Relative to oleate-treated cells, linoleate treatment led to increased activities of enzymes in hepatocytes.

\section{Effect on mRNA expression of fatty acid oxidation enzymes and PPARa in hepatocytes}

A significant up-regulation in the mRNA expression of carnitine palmitoyl transferase I, acyl CoA oxidase and its transcription factor, PPAR $\alpha$, were observed in laurate-treated cells, relative to cells treated with other fatty acids. Cells treated with linoleate also showed a significant increase in the mRNA expression of carnitine palmitoyl transferase I, acyl CoA oxidase and PPAR $\alpha$, relative to oleate-treated cells (Fig. 2).

Effects of exogenous fatty acids and PPAR agonist on cell viability

MTT assay was used to measure the cell viability; results showed that fatty acid- and PPAR- $\alpha$ agonist-treated cells had the same vi- 

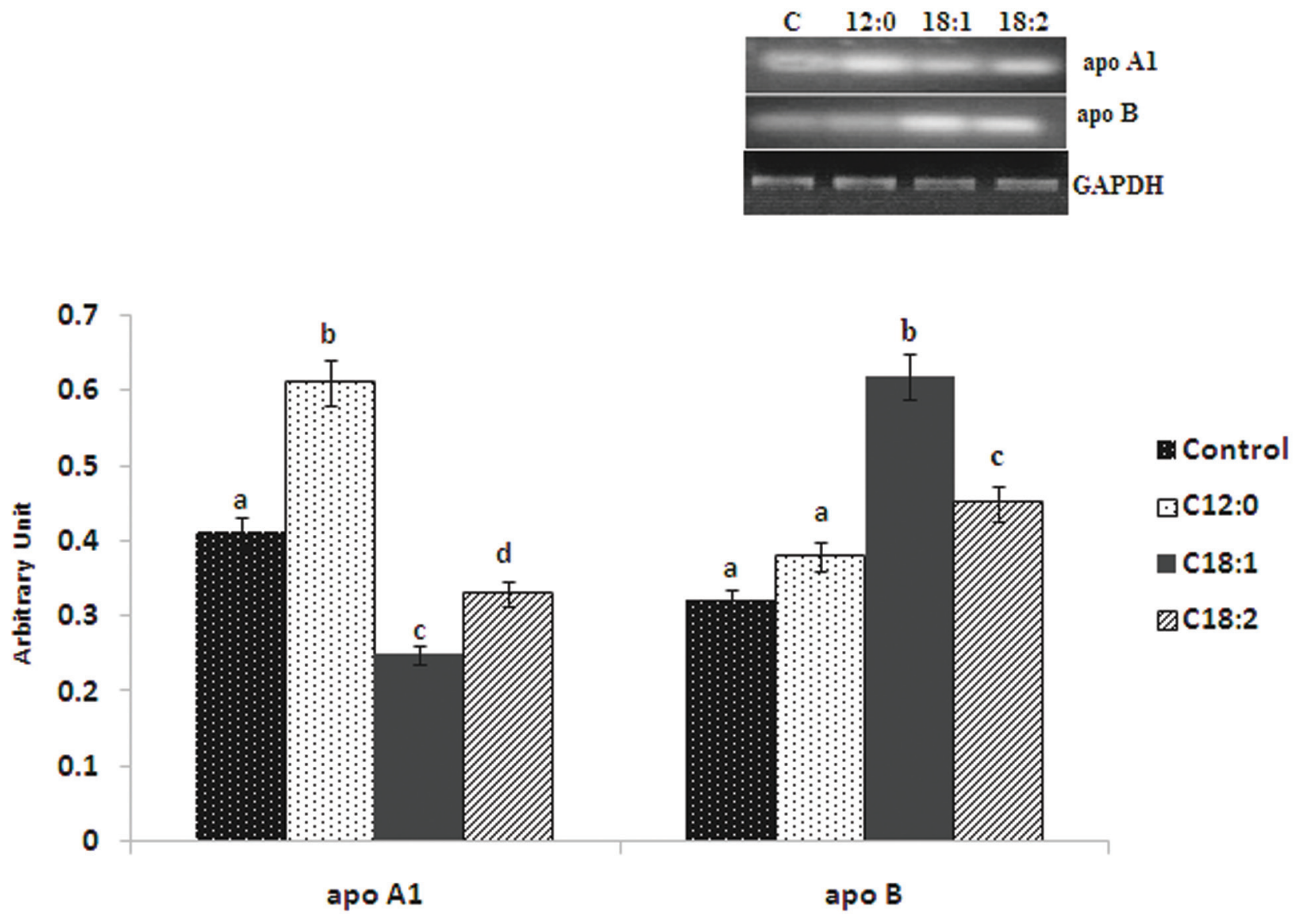

Fig. 1. Effect of exogenous fatty acids on the mRNA expression of apolipoproteins in hepatocytes. Values are mean \pm SEM of three separate experiments in triplicate. Values not sharing a common superscript differ significantly at $p<0.05$. Group I-control; Group II-500 $\mu \mathrm{M}$ laurate; Group III-500 $\mu \mathrm{M}$ oleate; Group IV-500 $\mu \mathrm{M}$ linoleate. Abbreviation: SEM, standard error of the mean.

ability as control cells during the experimental period (Fig. 3).

\section{Effect of PPARa ligands on fatty acid-mediated apolipoprotein secretion}

To study further the involvement of PPAR $\alpha$ signaling pathways on the fatty acid-mediated apolipoprotein secretion, isolated hepatocytes were cultured with different fatty acids (at $500 \mu \mathrm{M})$ in the presence or absence of the PPAR $\alpha$ agonist WY $14643(10 \mu \mathrm{M})$ for $12 \mathrm{~h}$. The presence of the PPAR $\alpha$ agonist WY 14643 decreased the amount of apolipoprotein B secreted into the medium, relative to cells treated with fatty acids. Laurate treatment also led to a significant decrease in apolipoprotein B secretion relative to cells treated with oleate and linoleate alone; moreover, laurate coincubation did not inhibit the effect of PPAR $\alpha$ agonist on apolipoprotein B secretion relative to cells cultured in combination with PPAR $\alpha$ agonist along with other fatty acids.

However, cells treated with oleate increased the apolipoprotein $\mathrm{B}$ secretion into the medium and inhibited the effect of PPAR $\alpha$ agonist on coincubation, relative to laurate or linoleate co-treatment with PPAR $\alpha$ agonist. Linoleate treatment also showed a significant increase in apolipoprotein B secretion relative to cells treated with PPAR $\alpha$ agonist and laurate. But, the effect of PPAR $\alpha$ agonist on apolipoprotein B secretion was not remarkably inhibited by linoleate cotreatment relative to lauric acid cotreatment with PPARo agonist. The inhibitory effect of PPAR $\alpha$ agonist on apolipoprotein B secretion was maximum in cells when cotreated with lauric acid followed by linoleate and oleate (Fig. 4). These results may suggest that this effect of fatty acids on apolipoprotein $\mathrm{B}$ secretion is partly mediated via a PPAR $\alpha$-dependent pathway in hepatocytes.

Treatment with the PPAR $\alpha$ agonist WY 14643 led to a significant increase in the apolipoprotein A1 secretion, relative to other fatty acids. Laurate treatment also showed an increased apolipo-

Table 2. Effect of exogenous fatty acids on the activities of fatty acid oxidation enzymes in hepatocytes

\begin{tabular}{llllll}
\hline & Group I & Group II & Group III & Group IV & $p$-value \\
\hline Carnitine palmitoyl transferase I $^{*}$ & $0.16 \pm 0.01^{\mathrm{a}}$ & $0.45 \pm 0.04^{\mathrm{b}}$ & $0.19 \pm 0.02^{\mathrm{c}}$ & $0.25 \pm 0.03^{\mathrm{d}}$ & $<0.05$ \\
Acyl CoA oxidase $^{*}$ & $0.15 \pm 0.01^{\mathrm{a}}$ & $0.39 \pm 0.04^{\mathrm{b}}$ & $0.17 \pm 0.02^{\mathrm{c}}$ & $0.23 \pm 0.03^{\mathrm{d}}$ & $<0.05$ \\
\hline
\end{tabular}

Values are mean \pm SEM of three separate experiments in triplicate. Values not sharing a common superscript differ significantly at $p<0.05$. Group I-control; Group II-500 $\mu \mathrm{M}$ laurate; Group III-500 $\mu \mathrm{M}$ oleate; Group IV- $500 \mu \mathrm{M}$ linoleate. *U/mg protein. Abbreviation: SEM, standard error of the mean. 


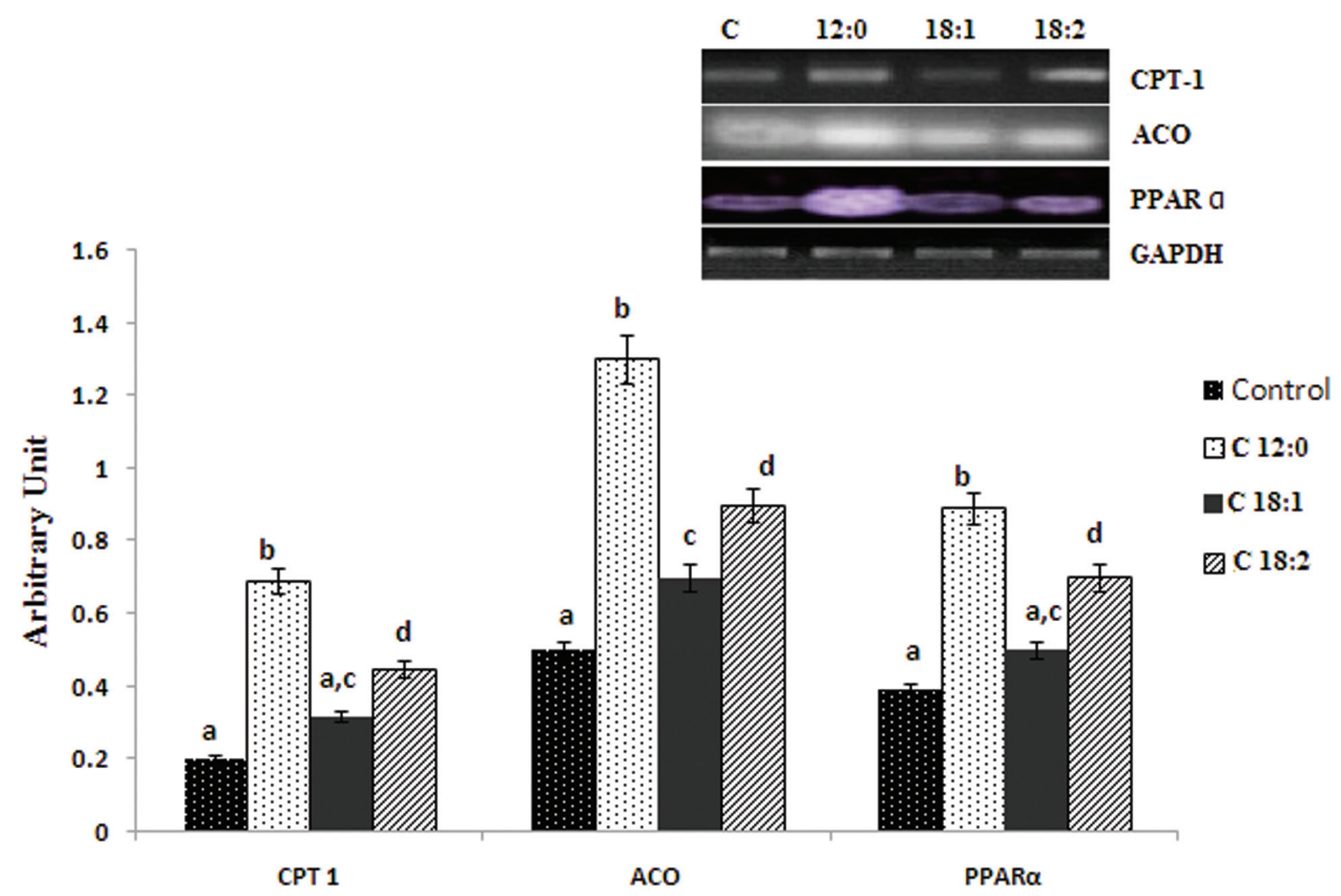

Fig. 2. Effect of exogenous fatty acids on the mRNA expression of fatty acid oxidation enzymes and PPAR $\alpha$ in hepatocytes. Values are mean \pm SEM of three separate experiments in triplicate. Values not sharing a common superscript differ significantly at $p<0.05$. Group I-control; Group II-500 $\mu \mathrm{M}$ laurate; Group III-500 $\mu \mathrm{M}$ oleate; Group IV-500 $\mu \mathrm{M}$ linoleate. Abbreviations: PPAR $\alpha$, peroxisome proliferator-activated receptor alpha; SEM, standard error of the mean.

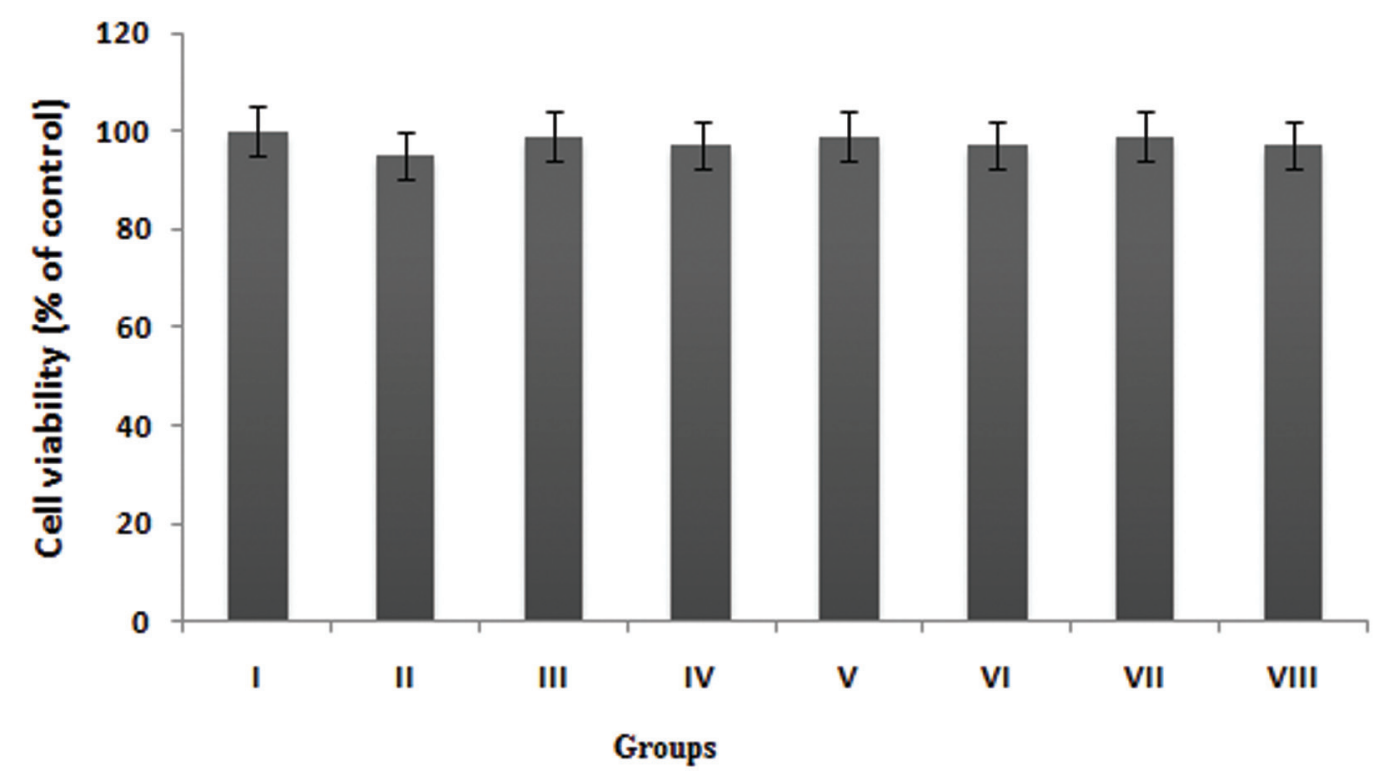

Fig. 3. Effects of exogenous fatty acids and WY 14643 on cell viability. Values are means \pm SEM of three independent experiments. I-control; II-WY 14643 $(10 \mu \mathrm{M})$; III-laurate $(500 \mu \mathrm{M})$; IV-laurate $(500 \mu \mathrm{M})+$ WY $14643(10 \mu \mathrm{M})$; V-oleate $(500 \mu \mathrm{M})$; VI-oleate $(500 \mu \mathrm{M})+$ WY $14643(10 \mu \mathrm{M}) ;$ VII-linoleate $(500 \mu \mathrm{M})$; VIII-linoleate $(500 \mu \mathrm{M})+(10 \mu \mathrm{M})$ WY 14643. Abbreviation: SEM, standard error of the mean. 


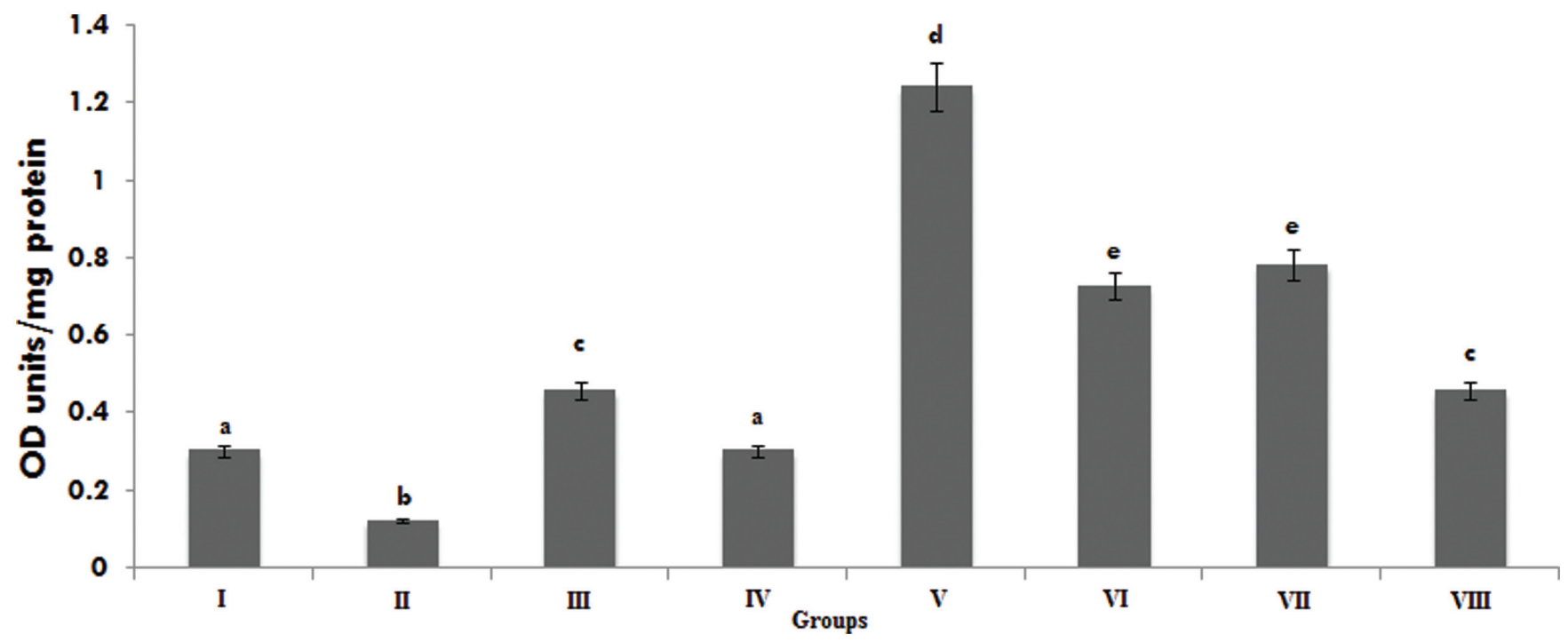

Fig. 4. Effect of PPAR $\alpha$ ligands on fatty acid-mediated apolipoprotein B secretion. Values are mean \pm SEM of three separate experiments in triplicate. Values not sharing a common superscript differ significantly at $p<0.05$. I-control; II-WY $14643(10 \mu \mathrm{M})$; III-laurate (500 $\mu \mathrm{M})$; IV-laurate (500 $\mu \mathrm{M})+$ WY 14643 (10 $\mu \mathrm{M})$; V-oleate $(500 \mu \mathrm{M})$; VI-oleate $(500 \mu \mathrm{M})+$ WY $14643(10 \mu \mathrm{M})$; VII-linoleate $(500 \mu \mathrm{M})$; VIII-linoleate $(500 \mu \mathrm{M})+(10 \mu \mathrm{M})$ WY 14643 . Abbreviations: PPAR peroxisome proliferator-activated receptor alpha; SEM, standard error of the mean.

protein A1 secretion, relative to those treated with oleate and linoleate alone. Co-incubation of laurate with agonist did not inhibit the effect of PPAR $\alpha$ agonist on apolipoprotein A1 secretion. Hepatocytes treated with oleate showed a significant decrease in apolipoprotein A1 secretion into the medium and inhibited the effect of PPAR $\alpha$ agonist on apolipoprotein A1 secretion. Even though linoleate treatment enhanced the apolipoprotein A1 secretion into the medium, not much significant difference was observed compared to the oleate treatment. Coincubation of linoleate did not inhibit the effect of PPAR $\alpha$ agonist on apolipoprotein A1 secretion relative to oleate cotreatment (Fig. 5). Among the three different fatty acid-treated groups, the maximum increase in apolipoprotein A1 secretion was observed in cells treated with laurate, followed by linoleate and oleate. Studies using PPAR $\alpha$ agonist confirmed that the effect of fatty acids on apolipoprotein secretion by hepatocytes is mediated at least in part via a PPAR $\alpha$ pathway.

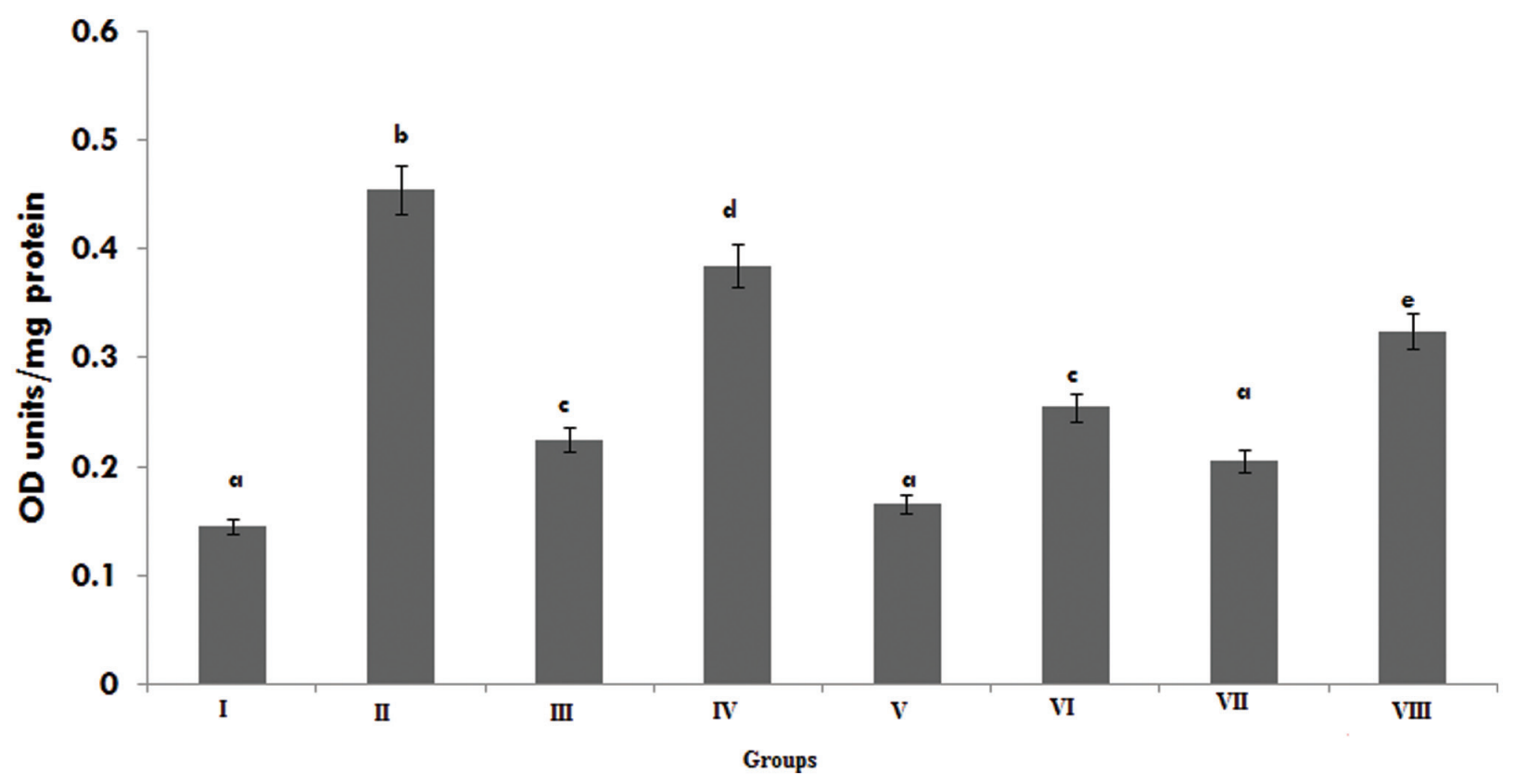

Fig. 5. Effect of PPAR $\alpha$ ligands on fatty acid-mediated apolipoprotein A1 secretion. Values are mean \pm SEM of three separate experiments in triplicate. Values not sharing a common superscript differ significantly at $p<0.05$. I-control; II-WY $14643(10 \mu \mathrm{M})$; III-laurate (500 $\mu \mathrm{M})$; IV- laurate (500 $\mu \mathrm{M})+$ WY 14643 $(10 \mu \mathrm{M})$; V-oleate $(500 \mu \mathrm{M})$; VI-oleate $(500 \mu \mathrm{M})+$ WY $14643(10 \mu \mathrm{M})$; VII-linoleate $(500 \mu \mathrm{M})$; VIII-linoleate $(500 \mu \mathrm{M})+(10 \mu \mathrm{M}) \mathrm{WY} 14643$. Abbreviations: PPAR $\alpha$, peroxisome proliferator-activated receptor alpha; SEM, standard error of the mean. 

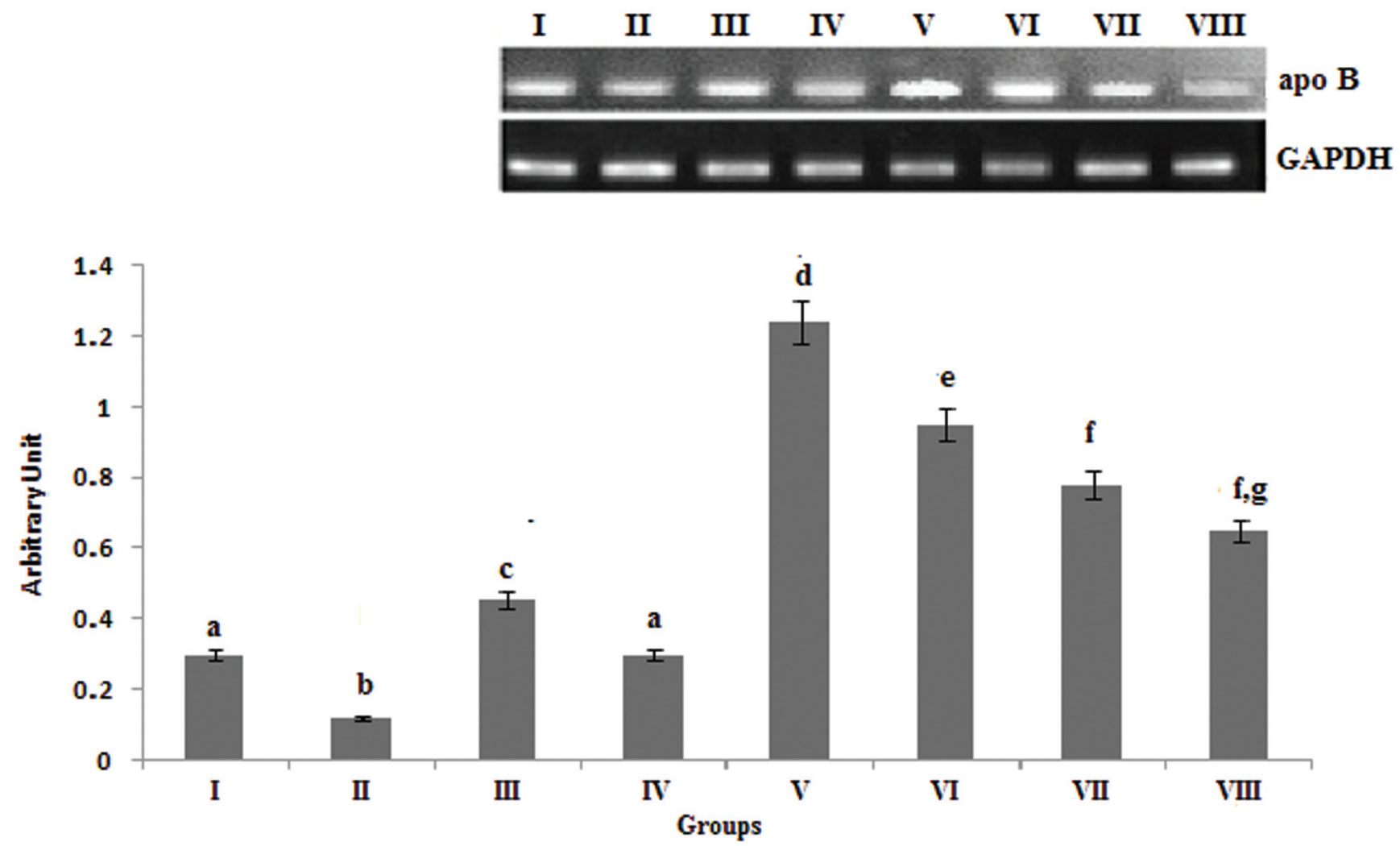

Fig. 6. Effect of PPAR $\alpha$ ligands on fatty acid-mediated mRNA expression of apolipoprotein B. Values are mean \pm SEM of three separate experiments in triplicate. Values not sharing a common superscript differ significantly at $p<0.05$. I-control; II-WY $14643(10 \mu \mathrm{M})$; III-laurate (500 $\mu \mathrm{M})$; IV-laurate (500 $\mu \mathrm{M})$ + WY $14643(10 \mu \mathrm{M})$; V-oleate $(500 \mu \mathrm{M})$; VI-oleate $(500 \mu \mathrm{M})+$ WY $14643(10 \mu \mathrm{M})$; VII-linoleate $(500 \mu \mathrm{M})$; VIII-linoleate $(500 \mu \mathrm{M})+(10 \mu \mathrm{M}) \mathrm{WY} 14643$. Abbreviations: PPAR $\alpha$, peroxisome proliferator-activated receptor alpha; SEM, standard error of the mean.

\section{Effect of PPARa ligands on fatty acid-mediated mRNA expres- sion of apolipoprotein}

Hepatocytes treated with PPAR $\alpha$ agonist decreased the mRNA expression of apolipoprotein B compared to other groups. Similarly, cells treated with laurate decreased the mRNA expression of apolipoprotein B relative to cells treated with other fatty acids; moreover, cotreatment of laurate did not inhibit the effect of PPAR $\alpha$ agonist on apolipoprotein B mRNA expression compared to cells treated with a combination of agonist with other fatty acids. Relative to other fatty acids, however, the oleate treatment led to an up-regulation in mRNA expression of apolipoprotein B and also inhibited the effect of PPAR $\alpha$ on apolipoprotein B mRNA expression on coincubation. Cells treated with linoleate also up-regulated the apolipoprotein B mRNA expression compared to cells treated with laurate. Relative to oleate co-treated cells, the linoleate cotreatment did not produce much inhibition on apolipoprotein B mRNA expression by PPAR $\alpha$ agonist in hepatocytes (Fig. 6).

Treatment with PPAR $\alpha$ agonist showed a significant increase in the mRNA expression of apolipoprotein A1 in hepatocytes compared to other groups. Laurate treatment also showed an increased mRNA expression of apolipoprotein A1 relative to cells treated with oleate and linoleate. Coincubation of PPAR $\alpha$ agonist with laurate did not inhibit the effect of agonist. Meanwhile, oleate treatment showed a significant decrease in apolipoprotein A1 mRNA expression compared to laurate treated cells. Furthermore, oleate cotreatment inhibited the effect of agonist on apolipopro- tein A1 expression (Fig. 7). Hepatocytes incubated with linoleate showed decreased mRNA expression of apolipoprotein A1 compared to those treated with laurate. Compared to oleate cotreated cells, coincubation of PPAR $\alpha$ agonist with linoleate caused less inhibition of the apolipoprotein A1 mRNA expression by PPAR $\alpha$ agonist. These results further confirm that fatty acid-induced apolipoprotein synthesis is transcriptionally regulated by PPAR $\alpha$ in hepatocytes.

\section{Effect of PPARa ligands on mRNA expression of carnitine pal- mitoyl transferase I and acyl CoA oxidase in hepatocytes}

In the presence of PPAR $\alpha$ agonist WY 14643 there was an upregulation in the mRNA expression of carnitine palmitoyl transferase I and acyl CoA oxidase in hepatocytes compared to other fatty acids (Fig. 8). Treatment with laurate also showed a significant increase in the expression of these genes and cotreatment with laurate did not inhibit the effect of agonist on mRNA expression relative to cells treated with oleate and linoleate. Meanwhile, the mRNA expression of carnitine palmitoyl transferase I and acyl CoA oxidase was decreased by oleate treatment and inhibited the effect of agonist on the gene expressions (carnitine palmitoyl transferase I and acyl CoA oxidase) in hepatocytes during coincubation. Hepatocytes treated with linoleate, however, showed increased expression of carnitine palmitoyl transferase I and acyl CoA oxidase compared to those treated with oleate. Furthermore, linoleate cotreatment did not inhibit the effect of PPAR $\alpha$ agonist 


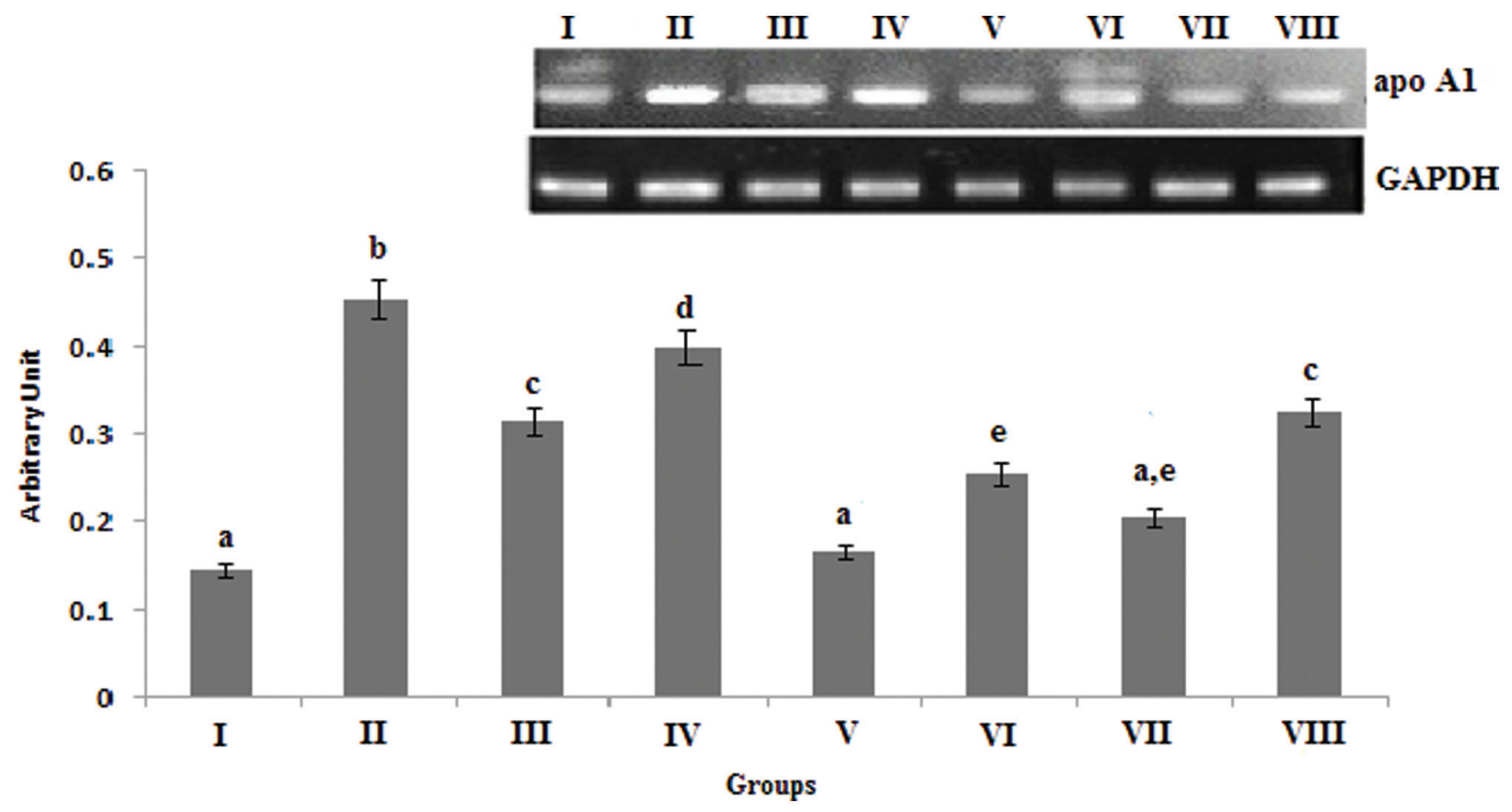

Fig. 7. Effect of PPAR $\alpha$ ligands on fatty acid-mediated mRNA expression of apolipoprotein A1. Values are mean \pm SEM of three separate experiments in triplicate. Values not sharing a common superscript differ significantly at $p<0.05$. I-control; II-WY $14643(10 \mu \mathrm{M})$; III-laurate $(500 \mu \mathrm{M})$; IV-laurate (500 $\mu \mathrm{M})$ + WY $14643(10 \mu \mathrm{M})$; V-oleate $(500 \mu \mathrm{M})$; VI-oleate $(500 \mu \mathrm{M})+$ WY $14643(10 \mu \mathrm{M})$; VII-linoleate $(500 \mu \mathrm{M})$; VIII-linoleate $(500 \mu \mathrm{M})+(10 \mu \mathrm{M})$ WY 14643. Abbreviations: PPAR $\alpha$, peroxisome proliferator-activated receptor alpha; SEM, standard error of the mean.

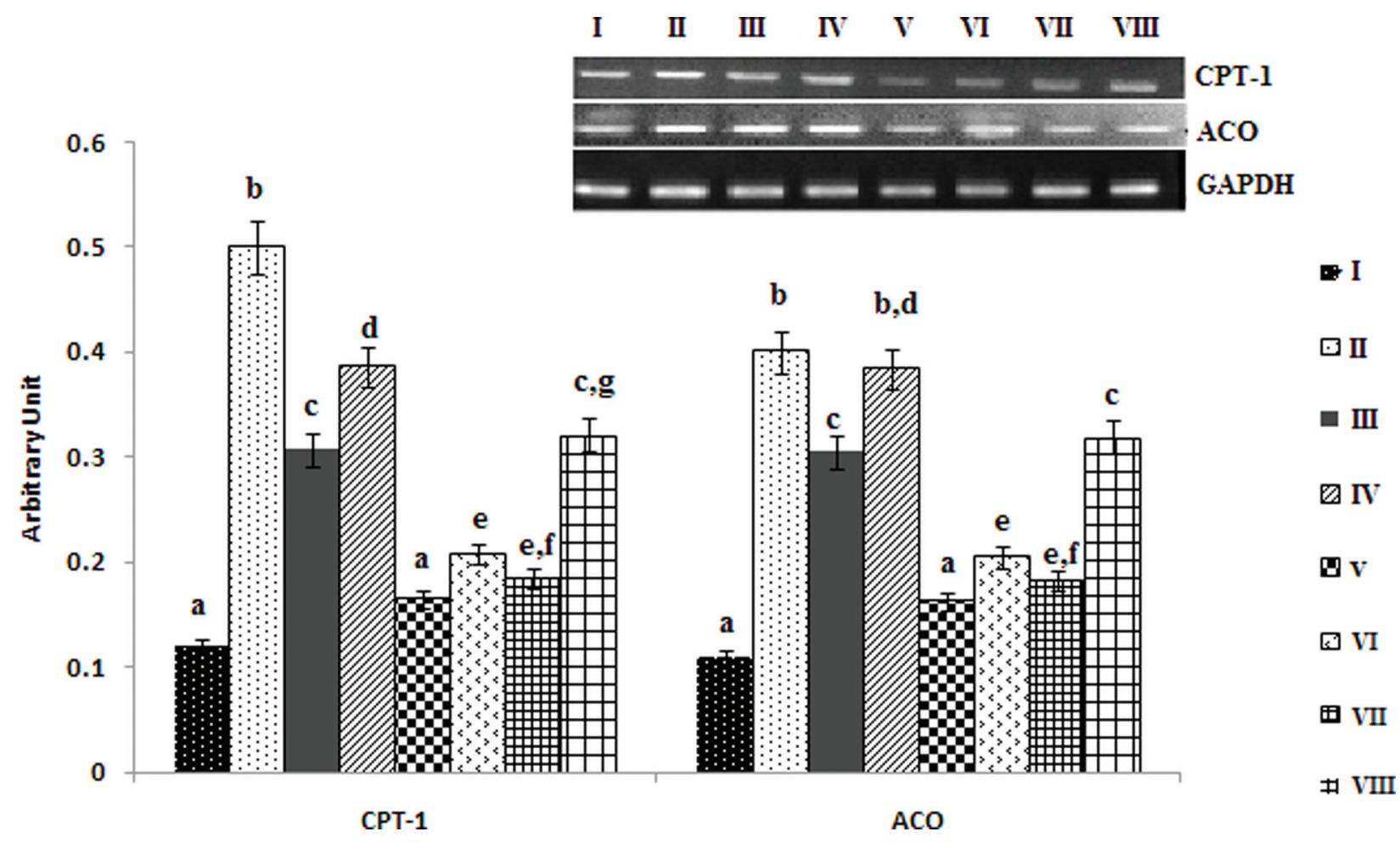

Fig. 8. Effect of PPAR $\alpha$ ligands on fatty acid mediated mRNA expression of carnitine palmitoyl transferase I and acyl CoA oxidase in hepatocytes. Values are mean \pm SEM of three separate experiments in triplicate. Values not sharing a common superscript differ significantly at $p<0.05$. I-control; II-WY 14643 $(10 \mu \mathrm{M})$; III-laurate $(500 \mu \mathrm{M})$; IV-laurate $(500 \mu \mathrm{M})+$ WY $14643(10 \mu \mathrm{M})$; V-oleate $(500 \mu \mathrm{M})$; VI-oleate $(500 \mu \mathrm{M})+$ WY $14643(10 \mu \mathrm{M}) ;$ VII-linoleate $(500 \mu \mathrm{M})$; VIII-linoleate $(500 \mu \mathrm{M})+(10 \mu \mathrm{M})$ WY 14643. Abbreviations: PPAR $\alpha$, peroxisome proliferator-activated receptor alpha; SEM, standard error of the mean. 
relative to agonist and oleate cotreated cells. These results indicate that oxidation of fatty acids in hepatocytes is also mediated via PPAR $\alpha$-dependent pathways.

\section{Discussion}

Results obtained indicate that the nature of fatty acid has a role in influencing apolipoprotein secretion from and fatty acid oxidation in hepatocytes. Among the three different fatty acids investigated, laurate showed a significant reduction in apolipoprotein B secretion relative to oleate and linoleate treatment. Yet, increased apolipoprotein A1 secretion was observed in the case of laurate, followed by linoleate and oleate. These changes in apolipoprotein secretion may be due to the fatty acid-mediated differential regulation of apolipoprotein expression at the mRNA level. It is clear from our results that laurate treatment up-regulated the mRNA expression of apolipoprotein A1 in hepatocytes relative to cells treated with oleate and linoleate. In contrast, there was a downregulation in apolipoprotein B mRNA expression in hepatocytes when treated with laurate, which correlated with the decreased apolipoprotein B secretion into the media.

These observations clearly revealed that the apolipoprotein secretion by the hepatocytes directly correlated with the corresponding mRNA expressions in hepatocytes. Previous reports on the differential effect of fatty acids on apolipoprotein B secretion revealed that oleic acid increases apolipoprotein B secretion by $239 \%$, followed by linoleic acid (164\%) and lauric acid 32\%. ${ }^{27}$ Our observations were also consistent with these reports. Cells treated with oleate showed maximum apolipoprotein B secretion compared to laurate and linoleate treatment. There are reports that oleic acid exerts a concentration-dependent increase in apolipoprotein B secretion into the medium, followed by saturated and polyunsaturated fatty acids. This might be due to the fact that oleic acid can influence the synthesis and secretion of apolipoprotein B in hepatocytes, probably by affecting cholesterol/cholesteryl ester formation, which may be a critical component in the secretion of apolipoprotein B as lipoproteins. ${ }^{16}$ In addition, oleic acid can increase the secretion of apolipoprotein B from HepG2 cells by stimulating its translocation across the endoplasmic reticulum and by preventing its degradation by a ubiquitin-dependent proteosome pathway. ${ }^{28,29}$ These might be the reasons for increased apolipoprotein B secretion in hepatocytes treated with oleate compared to other groups.

It is well established that all lipoproteins share a common structure, consisting of a neutral lipid core of triacylglycerol and cholesterol esters surrounded by a surface monolayer of phospholipids, un-esterified cholesterol and specific proteins called apolipoproteins. The assembly and secretion of lipoproteins are complex processes that occur in the lumen of the Golgi apparatus. ${ }^{30}$ These processes mainly involve the synthesis of apolipoproteins in the rough endoplasmic reticulum and the synthesis of lipids in the smooth endoplasmic reticulum, followed by their assembly. It has been reported that the nature of fatty acids differentially influences the synthesis and secretion of lipoproteins in the hepatocytes. ${ }^{27}$

Moreover, dietary fat type can differentially modulate the activity and expression of fatty acid oxidation enzymes. ${ }^{31}$ To examine how those fatty acids present in dietary oils can influence fatty acid oxidation, hepatocytes were maintained in a medium containing the major fatty acids present in common dietary oils, which vary in their degrees of saturation. Cell viability assays revealed that the exogenous fatty acid-treated cells had the same viability as control cells. Results showed that laurate treatment increases the activity of enzymes involved in $\beta$-oxidation of fatty acids (viz. car- nitine palmitoyl transferase I and acyl CoA oxidase in hepatocytes) compared to other fatty acid-treated groups. Further investigations revealed that laurate up-regulates the mRNA expression of carnitine palmitoyl transferase I and acyl CoA oxidase in hepatocytes, which might be the reasons for increased activity of these enzymes in hepatocytes. A noticeable reduction in carnitine palmitoyl transferase I activity was previously shown to be associated with decreased $\beta$-oxidation of fatty acid in hepatocytes. ${ }^{32}$

There is evidence that dietary supplementation of mediumchain fatty acids suppresses the fat deposition through enhanced fatty acid oxidation in animals and humans. ${ }^{33}$ Studies have shown that short and medium chain fatty acids present in dietary oils are mostly absorbed through the hepatic portal vein and become oxidized rapidly by both mitochondrial and peroxisomal pathways, and that they are less effectively incorporated into tissue lipids than the long chain fatty acids. ${ }^{34,35}$ The metabolic fate of lauric acid in cultured rat hepatocytes have shown that lauric acid was rapidly taken up by the cells and its incorporation into cellular lipids was low. ${ }^{36}$ In addition, in vivo laurate supplementation increases fatty acid oxidation at a higher rate in liver. ${ }^{37}$ Hepatocytes exposed to oleate showed the maximum down-regulation in mRNA expression and activity of fatty acid oxidation enzymes, followed by linoleate. Previous reports have also suggested that linoleate has higher affinity for the mitochondrial fatty acid oxidation system than oleate in isolated rat liver mitochondria. ${ }^{38}$

Furthermore, it is clear that the $\beta$-oxidation of fatty acids as well as the synthesis and assembly of lipoproteins are under transcriptional regulation of PPAR $\alpha .{ }^{8,39}$ PPAR $\alpha$ is a transcription factor belonging to the nuclear receptor superfamily, is activated by natural ligands, such as the fatty acids, and plays an important role in fatty acid oxidation. ${ }^{40} \mathrm{It}$ is reported that the genes encoding $\beta$-oxidation enzymes are transcriptionally regulated by PPAR $\alpha .{ }^{41}$ An up-regulation in the PPAR $\alpha$ expression was observed in hepatocytes treated with laurate, relative to cells treated with oleate and linoleate. Meanwhile, treatment with oleate decreased PPAR $\alpha$ expression in hepatocytes compared to other fatty acids.

PPARs are a unique set of fatty acid-regulated transcription factors controlling lipid metabolism. ${ }^{42}$ To be transcriptionally active, PPARs need to heterodimerize with the retinoid-X receptor. PPAR/ retinoid-X receptor heterodimers bind to DNA-specific sequences called peroxisome proliferator-response elements, consisting of an imperfect direct repeat of the consensus binding site for nuclear hormone receptors. To initiate transcriptional activity, the PPAR/ retinoid-X receptor complex has to be activated by ligand binding. Natural ligands of PPAR $\alpha$ include a variety of fatty acids as well as numerous fatty acid derivatives and compounds showing structural resemblance to fatty acids, including acyl-CoAs, oxidized fatty acids, eicosanoids, endocannabinoids, and phytanic acid. ${ }^{43,44}$ In addition, there are reports that medium chain fatty acids are the natural PPAR ligands and that supplementation of coconut oil up-regulates mRNA expression of PPAR $\alpha .{ }^{45,46}$ Our recent report also suggested that virgin coconut oil supplementation increases mRNA expression of PPAR $\alpha$ and its target genes involved in fatty acid oxidation, as compared with rats fed olive oil and sunflower oil. ${ }^{17}$ Upon ligand binding, the conformation of the receptor is altered, promoting high affinity interactions with coactivators that remodel chromatin structure and activate the transcriptional machinery. ${ }^{29}$

Many aspects of hepatic lipid metabolism are under control of PPAR $\alpha$. Regulation of lipid metabolism is mainly coordinated by liver, which actively metabolizes fatty acids as fuel and continuously produces very low-density lipoprotein particles to provide a constant supply of fatty acids to peripheral tissues. Clinical studies in humans have provided ample evidence that fibrate drugs effectively lower fasting plasma triglycerides and raise plasma high- 
density lipoprotein. ${ }^{47}$ At the molecular level, fibrates act as synthetic agonist for PPAR $\alpha$, indicating an important role of PPAR $\alpha$ in the control of lipoprotein metabolism. PPAR $\alpha$ activation lowers plasma triglycerides in part by reducing very low-density lipoprotein production. ${ }^{48}$ There are reports that PPAR $\alpha$ deficiency increases the secretion and serum levels of apolipoprotein B-containing lipoproteins. ${ }^{8}$ Moreover, PPAR $\alpha$ activation increases plasma highdensity lipoprotein via the induction of hepatic apolipoprotein A1 and apolipoprotein AII expression in humans. ${ }^{49}$

In the last part of the study, involvement of PPAR $\alpha$ on fatty acid-mediated apolipoprotein secretion and fatty acid oxidation were studied. For this, hepatocytes were treated with different types of fatty acids in the presence or absence of WY 14643, a highly potent synthetic PPAR $\alpha$ agonist. Results indicate that treatment with laurate decreases the mRNA expression and secretion of apolipoprotein $\mathrm{B}$ in hepatocytes and that co-treatment did not inhibit the effect of PPAR $\alpha$ agonist on apolipoprotein B secretion. In addition, hepatocytes treated with laurate showed up-regulated mRNA expression and secretion of apolipoprotein A1, as well as increased fatty acid oxidation; the laurate treatment did not inhibit the effect of PPAR $\alpha$ agonist on fatty acid oxidation. There are reports that medium chain fatty acids are natural ligands for PPAR,,${ }^{45}$ and PPAR $\alpha$ activation up-regulates fatty acid oxidation-related genes, such as acyl CoA oxidase and carnitine palmitoyl transferase I, which suppresses postprandial lipidemia and lipid accumulation in enterocytes. ${ }^{50,51}$ Our study clearly proved that lauric acid may act as ligand for PPAR $\alpha$, which mediates its effects partly via the PPAR $\alpha$ pathway.

In conclusion, the present study clearly indicates that lauric acid, the major fatty acid present in oil extracted from coconut, acts as a natural ligand for PPAR $\alpha$, beneficially regulating secretion of apolipoproteins and enhancing fatty acid oxidation via the PPAR $\alpha$ signaling pathways in hepatocytes.

\section{Future research prospective}

Lauric acid, may act as a natural ligand for PPAR $\alpha$ and has a beneficial role in modulating apolipoprotein secretion as well as fatty acid oxidation. Since regulating the synthesis of endogenous apolipoprotein secretion would be an attractive therapeutic target for reducing the atherogenicity, lauric acid itself or lauric acid enriched dietary oils can be recommended as healthy dietary interventions for reducing the risk factors for atherosclerosis.

\section{Acknowledgments}

Financial assistance in the form of a research fellowship from the University of Kerala (grant number 5825/2009 to S. Arunima) is gratefully acknowledged. The University of Kerala had no role in the design of the study, analysis of the data or writing of the article.

\section{Conflict of interest}

The authors have no conflict of interests related to this publication.

\section{Author contributions}

Designing research (SA, TR), performing research (SA), analyzing data (SA, TR), writing paper (SA), and proofreading paper (TR).

\section{References}

[1] Lawrence GD. Dietary fats and health: dietary recommendations in the context of scientific evidence. Adv Nutr 2013;4(3):294-302. doi:10.3945/an.113.003657.

[2] Hegsted DM, Ausman LM, Johnson JA, Dallal GE. Dietary fat and serum lipids: an evaluation of the experimental data. Am J Clin Nutr 1993;57(6):875-883.

[3] Pischon T, Girman CJ, Sacks FM, Rifai N, Stampfer M J, Rimm EB. Nonhigh-density lipoprotein cholesterol and apolipoprotein B in the prediction of coronary heart disease in men. Circulation 2005;112(22):33753383. doi:10.1161/CIRCULATIONAHA.104.532499.

[4] Walldius G, Jungner I. Apolipoprotein B and apolipoprotein A-I: risk indicators of coronary heart disease and targets for lipid-modifying therapy. J Intern Med 2004;255(2):188-205. doi:10.1046/j.1365-2796. 2003.01276.x.

[5] Navab M, Hama SY, Cooke CJ, Anantharamaiah G M, Chaddha M, Jin $L$, et al. Normal high density lipoprotein inhibits three steps in the formation of mildly oxidized lowdensity lipoprotein: step 1. J Lipid Res 2000;41(9):1481-1494.

[6] Phillips MC. Apolipoprotein E isoforms and lipoprotein metabolism. IUBMB Life 2014;66(9):616-623. doi:10.1002/iub.1314.

[7] White AL, Graham DL, LeGros J, Pease RJ, Scott J. Oleate-mediated stimulation of apolipoprotein B secretion from rat hepatoma cells. A function of the ability of apolipoprotein B to direct lipoprotein assembly and escape presecretory degradation. J Biol Chem 1992;267(22):15657-15664.

[8] Lindén $D$, Alsterholm $M$, Wennbo $H$, Oscarsson J. PPAR alpha deficiency increases secretion and serum levels of apolipoprotein B-containing lipoproteins. J Lipid Res 2001;42(11):1831-1840.

[9] Mandard S, Müller M, Kersten S. Peroxisome proliferator-activated receptor $\alpha$ target genes. CMLS 2004;61(4):393-416. doi:10.1007/ s00018-003-3216-3.

[10] Fruchart JC, Duriez P, Staels B. Peroxisome proliferator-activated receptor alpha activators regulate genes governing lipoprotein metabolism, vascular inflammation and atherosclerosis. Curr Opin Lipidol 1999;10(3):245-257.

[11] Myerson M, Ngai C, Jones J, Holleran S, Ramakrishnan R, Berglund $L$, et al. Treatment with high-dose simvastatin reduces secretion of apolipoprotein Blipoproteins in patients with diabetic dyslipidemia. J Lipid Res 2005;46(12):2735-2744. doi:10.1194/jlr.M500335-JLR200.

[12] Arunima S, Rajamohan T. Effect of virgin coconut oil enriched diet on the antioxidant status and paraoxonase 1 activity in ameliorating the oxidative stress in rats - a comparative study. Food Funct 2013;4(9):1402-1409. doi:10.1039/c3fo60085h.

[13] Arunima S, Rajamohan T. Virgin coconut oil improves hepatic lipid metabolism in rats compared with copra oil, olive oil and sunflower oil. Indian J Exp Biol 2012;50(11):802-809.

[14] Sakai T, Jin FY, Kamanna VS, Kashyap ML. Albumin inhibits apolipoprotein Al and All production in human hepatoblastoma cell line (Hep G2): additive effects of oleate-albumin complex. Atherosclerosis 2000;149(1):43-49. doi:10.1016/S0021-9150(99)00292-0.

[15] Van Tol A, Terpstra AHM, Van den Berg P, Beynen AC. Dietary corn oil versus olive oil enhances HDL protein turnover and lowers HDL cholesterol levels in hamsters. Atherosclerosis 1999;147(1):87-94. doi:10.1016/S0021-9150(99)00167-7.

[16] Kumar NS, Abraham R, Kumar GS, Sudhakaran PR, Kurup PA. Effect of fatty acids on the synthesis and secretion of apolipoprotein $B$ by rat hepatocytes. J Biosci 1992;17(4):473-481. doi:10.1007/BF02720102.

[17] Arunima S, Rajamohan T. Influence of virgin coconut oil-enriched diet on the transcriptional regulation of fatty acid synthesis and oxidation in rats-a comparative study. Br J Nutr 2014;111(10):1782-1790. doi:10.1017/S000711451400004X.

[18] Seglen PO. Preparation of isolated rat liver cells. Methods Cell Biol 1976;13:29-83. doi:10.1016/S0091-679X(08)61797-5.

[19] Sudhakaran PR, Stamatoglou SC, Hughes RC. Modulation of protein synthesis and secretion by substratum in primary cultures of rat 
hepatocytes. Exp Cell Res 1986;167(2):505-516. doi:10.1016/00144827(86)90190-4.

[20] Hannah VC, Ou J, Luong A, Goldstein JL, Brown MS. Unsaturated fatty acids down-regulate srebp isoforms $1 \mathrm{a}$ and $1 \mathrm{c}$ by two mechanisms in HEK-293 cells. J Biol Chem 2001;276(6):4365-4372. doi:10.1074/jbc. M007273200.

[21] Ide T, Watanabe M, Sugano M, Yamamoto I. Activities of liver mitochondrial and peroxisomal fatty acid oxidation enzymes in rats fed trans fat. Lipids 1987;22(1):6-10. doi:10.1007/BF02534867.

[22] Shimizu S, Yasui K, Tani Y, Yamada H. Acyl-CoA oxidase from Candida tropicalis. Biochem Biophys Res Commun 1979;91(1):108-113. doi:10.1016/0006-291X(79)90589-8.

[23] Mosmann TJ. Rapid colorimetric assay for cellular growth and survival: application to proliferation and cytotoxicity assays. J Immunol Methods 1983;65(1-2):55-63. doi:10.1016/0022-1759(83)90303-4.

[24] Lin RC. Quantification of apolipoproteins in rat serum and in cultured rat hepatocytes by enzyme-linked immunosorbent assay. Anal Biochem 1986;154(1):316-326. doi:10.1016/0003-2697(86)90531-2.

[25] Lowry OH, Rosebrough NJ, Farr AL, Randall RJ. Protein measurement with Folin phenol reagent. J Biol Chem 1951;193(1):265-275.

[26] Chomczynski P, Mackey K. Substitution of chloroform by bromochloropropane in the single-step method of RNA isolation. Anal Biochem 1995;225(1):163-164. doi:10.1006/abio.1995.1126.

[27] Arrol S, Mackness MI, Durrington PN. The effects of fatty acids on apolipoprotein B secretion by human hepatoma cells (HEP G2). Atherosclerosis 2000;150(2):255-264. doi:10.1016/S0021-9150(99) 00374-3.

[28] Dixon JL, Furukawa S, Ginsberg HN. Oleate stimulates secretion of apolipoprotein B-containing lipoproteins from Hep G2 cells by inhibiting early intracellular degradation of apolipoprotein B. J Biol Chem 1991;266(8):5080-5086.

[29] Yeung SJ, Chen SH, Chan L. Ubiquitin-proteasome pathway mediates intracellular degradation of apolipoprotein B. Biochemistry 1996;35(43):13843-13848. doi:10.1021/bi9618777.

[30] Olofsson SO, Asp L, Borén J. The assembly and secretion of apolipoprotein B-containing lipoproteins. Curr Opin Lipidol 1999;10(4):341346.

[31] Priore P, Stanca E, Gnoni GV, Siculella L. Dietary fat types differentially modulate the activity and expression of mitochondrial carnitine/acylcarnitine translocase in liver. Biochim Biophys Acta 2012;1821(10):1341-1349. doi:10.1016/j.bbalip.2012.07.008.

[32] Serviddio G, Giudetti AM, Bellanti F, Priore P, Rollo T, Tamborra R, et al. Oxidation of hepatic carnitine palmitoyl transferase-I (CPTI) impairs fatty acid betaoxidation in rats fed a methionine-choline deficient diet. PloS One 2011;6(9):e24084. doi:10.1371/journal. pone.0024084.

[33] Nagao K, Yanagita T. Medium-chain fatty acids: functional lipids for the prevention and treatment of the metabolic syndrome. Pharmacol Res 2010;61(3):208-212. doi:10.1016/j.phrs.2009.11.007.

[34] Caspary WF. Physiology and pathophysiology of intestinal absorption. Am J Clin Nutr 1992;55(Suppl 1):S299-S308.

[35] Papamandjaris AA, MacDougall DE, Jones PJ. Medium chain fatty acid metabolism and energy expenditure: obesity treatment implications. Life Sci 1998;62(14):1203-1215. doi:10.1016/S0024-3205(97)011430.

[36] Rioux V, Daval S, Guillou H, Jan S, Legrand P. Although it is rapidly metabolized in cultured rat hepatocytes, lauric acid is used for protein acylation. Reprod Nutr Develop 2003;43(5):419-430. doi:10.1051/ rnd:2003036.

[37] Piot C, Hocquette JF, Veerkamp JH, Durand D, Bauchart D. Effect of dietary coconut oil on fatty acid oxidation capacity of the liver, the heart and skeletal muscles in preruminant calf. Br J Nutr 1999;82(4):299308. doi:10.1017/S0007114599001506.

[38] Björntorp P. Rates of oxidation of different fatty acids by isolated rat liver mitochondria. J Biol Chem 1968;243(9):2130-2133.

[39] Latruffe N, Cherkaoui Malki M, Nicolas-Frances V, Jannin B, Clemencet MC, Hansmannel F, et al. Regulation of the peroxisomal boxidation dependent pathway by peroxisome proliferator activated receptor $\alpha$ and kinases. Biochem Pharmacol 2000;60(8):1027-1032. doi:10.1016/s0006-2952(00)00416-0.

[40] Reddy JK, Hashimoto T. Peroxisomal b-oxidation and peroxisome proliferator-activated receptor a: an adaptive metabolic system. Annu Rev Nutr 2001;21:193-230. doi:10.1146/annurev.nutr.21.1.193.

[41] Desvergne B, Wahli W. Peroxisome proliferator-activated receptors: nuclear control of metabolism. Endocr Rev 1999;20(5):649-688. doi:10.1210/edrv.20.5.0380.

[42] Varga T, Czimmerer Z, Nagy L. PPARs are a unique set of fatty acid regulated transcription factors controlling both lipid metabolism and inflammation. Biochim Biophys Acta 2011;1812(8):1007-1022. doi:10.1016/j.bbadis.2011.02.014.

[43] Keller H, Dreyer C, Medin J, Mahfoudi A, Ozato K, Wahli W. Fatty acids and retinoids control lipid metabolism through activation of peroxisome proliferator-activated receptor-retinoid $\mathrm{X}$ receptor heterodimers. Proc Natl Acad Sci USA 1993;90(6):2160-2164.

[44] Kliewer SA, Sundseth SS, Jones SA, Brown PJ, Wisely GB, Koble CS, et al. Fatty acids and eicosanoids regulate gene expression through direct interactions with peroxisome proliferator-activated receptors $\alpha$ and $\gamma$. Proc Natl Acad Sci USA 1997;94(9):4318-4323.

[45] Liberato MV, Nascimento AS, Ayers SD, Lin JZ, Cvoro A, Silveira RL, et al. Medium chain fatty acids are selective peroxisome proliferator activated receptor (PPAR) $y$ activators and pan-PPAR partial agonists. PLoS One 2012;7(5):e36297. doi:10.1371/journal.pone.0036297.

[46] Bonilla S, Redonnet A, Noel-Suberville C, Pallet V, Garcin H, Higueret P. High-fat diets affect the expression of nuclear retinoic acid receptorin rat liver. Br J Nutr 2000;83(6):665-671. doi:10.1017/ S0007114500000842.

[47] Rubins HB, Robins SJ, Collins D, Fye CL, Anderson JW, Elam MB, et al. Gemfibrozil for the secondary prevention of coronary heart disease in men with low levels of high-density lipoprotein cholesterol. N Eng J Med 1999;341(6):410-418. doi:10.1056/NEJM199908053410604.

[48] Kersten S. Peroxisome proliferator activated receptors and lipoprotein metabolism. PPAR Res 2008;2008:132960. doi:10.1155/2008/ 132960.

[49] Gervois P, Torra IP, Fruchart J C, Staels B. Regulation of lipid and lipoprotein metabolism by PPAR activators. Clin Chem Lab Med 2000;38(1):3-11. doi:10.1515/CCLM.2000.002.

[50] Pineda Torra I, Gervois P, Staels B. Peroxisome proliferator activated receptor a in metabolic disease, inflammation, atherosclerosis and aging. Curr Opin Lipidol 1999;10(2):151-159.

[51] Kimura R, Takahashi N, Murota K, Yamada Y, Niiya S, Kanzaki N, et al. Activation of peroxisome proliferator-activated receptor-a (PPAR $\alpha$ ) suppresses postprandial lipidemia through fatty acid oxidation in enterocytes. Biochem Biophys Res Commun 2011;410(1):1-6. doi:10.1016/j.bbrc.2011.05.057. 